\title{
Review
}

\section{Worldly ethics: Democratic politics and care for the world}

\author{
Ella Myers \\ Duke University Press, Durham, NC, 2013, 232 pp., ISBN: 978-0822353997 \\ Contemporary Political Theory (2015) 14, e4-e7. doi:10.1057/cpt.2014.31; \\ published online 25 November 2014
}

Wordly Ethics is a beautifully written and erudite intervention in debates about the relationship between ethical disposition and political action. Ella Myers approaches the turn to ethos from the perspective of a sympathetic critic. Instead of reiterating familiar critiques of the universalism, abstraction and ahistoricism of normative political theory, she focuses her attention on 'the new ethics'. This ethical turn draws on continental thought, particularly the late work of Michel Foucault and Emmanuel Levinas. Myers focuses on two main approaches: the Foucaultian 'care of oneself' and the Levinasian 'responsibility for the other'. She is a careful reader of these theorists, and also shows how their ideas have been taken up by contemporary political theorists such as William Connolly, Simon Critchley and Judith Butler. Her evaluation comes across clearly when she describes these two approaches as the therapeutic and charitable models of ethics. According to Myers, both of these approaches are ultimately depoliticizing and therefore not particularly democratic. The alternative she proposes is more Arendtian in tenor. She describes it as a 'contentious and collaborative care for the world'.

In the first chapter, Myers explains why the ethics of self-care is not democratic. She concedes that a therapeutic approach may sometimes be a first step towards democratic participation, but she argues that it may just as easily lead to narcissism or even domination. A closer look at Foucault's late work shows why this is true. Foucault developed his new aesthetic approach to the self through readings of ancient texts. Myers points out that these Greek authors understood self-fashioning to be preparation for rule over others. This should remind us that the link between self-care and political equality is not something we can take for granted. Some of Myers' other criticisms of Foucault are familiar but still worth reiterating in this context. For example, she notes the difficulty of distinguishing between types of 'care of the self' that reproduce power and those that resist it. In his later works, Foucault called for 'action by the self on the self' but never fully explained how we can be sure the selffashioning agent is not also the subject of power. 
Do contemporary Foucaultians provide a richer account of the link between selfcare, democratic ethos and democratic politics? According to Myers, they do not. Myers focuses on Connolly's depiction of the relationship between self-care and democratic ethos. Connolly emphasizes that the arts of the self are important because they cultivate democratic sensibilities such as critical responsiveness and agonistic respect. He also suggests that the self is multivalent and this makes it possible to mobilize certain dispositions against other dispositions, habits and assumptions. Myers argues that the connection between self-formation and political action remains underspecified: What motivates people to engage in critical self-fashioning in the first place, and why should we be confident that such reflexivity will generate a democratic ethos rather than narcissism? For Myers, the answer to the first question is 'democratic association'. Working together with others to improve the world is a praxis that motivates us to reconsider our own habits and provides a social context that enables us to change them.

This emphasis on intersubjectivity might seem to suggest an affinity with the ethics of responsibility, an approach influenced by the work of Emmanuel Levinas. The second chapter of the book, however, highlights the difference between worldly ethics and the ethics of responsibility. The key idea of the ethics of responsibility is that the self is produced through an originary, asymmetrical encounter with the other, which inaugurates a limitless responsibility. According to Myers, this theory fails to explain the relationship between ethical responsibility for the concrete other and political responsibility in a world of multiple others with conflicting needs. Furthermore, while the content of this responsibility remains vague, it seems to point towards an obligation to provide for the basic material needs of specific individuals rather than to attend to broader structural change or ideological analysis. This unintentionally ends up reinforcing the liberal tendency to embrace charitable ethics and devalue democratic action. According to Myers, even Judith Butler's more explicitly political notion of 'precarity' is problematic because it still rests on the false promise of Levinasianism: the hope that mere exposure to the other will generate a sense of responsibility that motivates action to combat vulnerability and domination.

Many of these criticisms of Levinas are convincing and generally accepted in the secondary literature, but I would not go so far as to conflate the ethics of responsibility with 'charitable volunteerism'. Myers argues that charitable ethics is a kind of noblesse oblige: hierarchical, asymmetrical and non-reciprocal; it would be misleading, however, to characterize Levinas's self-other relationship in this way. He does describe the relationship as hierarchical, but the hierarchy stems from the way the self is subordinate to the other. The asymmetry is meant to emphasize that the other is not a projection of the self and the relationship is not one of contract and exchange. This account helps us think beyond the dominant categories of individualism, identity and a form of equality, which is actually the projection of the self onto the other. The face of the other is not the poor person whom I pity but rather the transcendent force that ruptures my sense of mastery and constitutes the self. 
Still, there is the vexing question of how this scene can be transposed into democratic politics, and Myers rightly points out that this is difficult and perhaps impossible to do. What would be a more compelling basis for a democratic ethos? In order to answer this question, Myers draws on Arendt's notion of amor mundi, or love of the world. Rather than caring for the self or the particular other, we must care for the world. Doing so requires associative democratic activity that involves both project-oriented solidarity and agonistic struggle. I think that this is correct, but yet I am more inclined to see this care for the world as linked to the aesthetics of the self and responsibility to the other rather than defined in opposition to them.

Throughout the book, Myers challenges the assumption that service to others and work on the self are necessarily politicizing. While they are not necessarily politicizing, I think they often are politicizing, but the strength of this relationship is difficult to assess using political theory. I can only present an anecdotal example to sketch how the connection could work. Before graduate school, I volunteered for Amnesty International helping political asylum seekers prepare their applications. While not exactly charity, this was based on the model of providing service to individuals in need. Yet, hearing the refugees' stories and then seeing their claims dismissed in the review process motivated me to participate in demonstrations against the proposed abolition of the constitutional right to asylum. I do not think this experience is unusual. Another more striking example was shared with me by an evangelical Christian I met in Florida. He had originally planned to engage in a straightforward act of charity - providing food to homeless people at his church - but when parishioners and neighbours protested, he came to realize that zoning ordinances restricted his ability to carry out his Christian duty. He literally could not care for the other without first attending to the world through political mobilization. Myers claims that dominant theories fail to explain the move from ethics to politics, but it is possible to provide such an account. Privileged individuals seldom have a direct experience of structural injustice. It is through encounter with those in need that they may come to recognize this injustice. Only then can it become 'a worldly thing' that we work together to change.

The last chapter of the book makes a somewhat surprising move, a turn from ethos to norms. Myers acknowledges that democratic association is a necessary but not sufficient condition for securing the ends that motivate her project. She introduces normative theory in order to explain what care of the world means and why we should prioritize it. The key concept is the 'common', and she argues that this entails commitment to fulfil basic needs and to develop human capabilities. A critic could respond that this argument is a fallacy because it derives ought from is; I mention this because Myers used the 'is-ought' issue as a reason to reject Butler's attempt to derive political obligation from the fact of precarity. I myself, however, do not endorse this line of critique. If it is turtles all the way down, as the great political theorist Dr Seuss once said, then we are left with only one possibility, and that is advancing normative arguments by relating them to other normative arguments that 
our audience or interlocutor will endorse. Thus, when Butler writes about precarity, I do not read this as making a claim from fact but rather drawing on the normative principle that we should strive to make life less precarious, a project that fits quite well with Myers' human capabilities approach.

Wordly Ethics examines an important topic with originality and nuance. One of the many strengths of the book is that it resists the temptation to use the concept of democracy to stand in for a disavowed normativity. By disarticulating democratic institutions from democratic ethos and norms, we can see how they fit together and how they sometimes come apart.

Margaret Kohn

University of Toronto, Toronto, Ontario, Canada M5S 3G3 